Journal of Humanities, Social and Management Sciences (JHSMS)

eISSN: 2788-4791 (online)

https:// doi.org/10.47264/idea.jhsms/3.1.4

Vol. 3, No. 1 (January-June 2022), 40-56

https://ideapublishers.org/index.php/jhsms

Research Article

\title{
Exploring the solidarity discourse on Islam and Muslims in the Australian press
}

\author{
Muhammad Junaid Ghauri*11 Amrat Haq $^{1}$ | Riffat Alam²
}

1. Department of Media \& Communication Studies, International Islamic University Islamabad, Pakistan.

2. Department of Mass Communication, Karakoram International University, Gilgit-Baltistan, Pakistan.

*Corresponding Author Emails: muhammad.junaid@iiu.edu.pk|mjghauri84@gmail.com

Received: December 4, $2021 \quad$ Accepted: January 31, $2022 \quad$ Published: February 13, 2022

\begin{abstract}
This paper is an attempt to explore whether and to what extent the Australian newspapers; The Age and The Australian, produced the "solidarity discourse" regarding Islam and Muslims during the time period January 01, 2016 to March 31, 2017. Edward Said's Orientalism and many other research findings suggest that there is clear evidence of positive in-group (Us/the West/the Occident) and negative out-group (Them/the Islam and Muslims/the East/the Orient) discourse in the representation of Islam and Muslims by global media. However, Jeffery C. Alexander asserts that the media being "communicative institution" of a society plays an important role of "civil repair" by producing a "solidarity discourse". His civil sphere theory proposes that the media as a "vital centre" highlight and generates common understanding of the solidarity which can resist "non-civil" polarization and radical actions in civil societies. The researcher has employed "Lexicalization" and "Ideological Square" approaches from Critical Discourse Analysis (CDA) paradigm proposed by van Dijk. The findings of this study show that The Age produced the "solidarity discourse" overwhelmingly by emphasizing on "understanding", "cohesion", and "we-ness". On the contrary, the "solidarity discourse" is entirely absent in the editorials of The Australian.
\end{abstract}

Keywords: solidarity discourse, vital centre, civil repair, civil sphere theory, critical discourse, critical discourse analysis, ideological square, lexicalization.

\section{How to Cite:}

Ghauri, M. J., Haq, A., \& Alam, R. (2022). Exploring the solidarity discourse on Islam and Muslims in the Australian press. Journal of Humanities, Social and Management Sciences (JHSMS), 3(1), 40-56. https://doi.org/10.47264/idea.jhsms/3.1.4

Publisher's Note: IDEA PUBLISHERS (IDEA Publications Group) stands neutral with regard to jurisdictional claims in the published maps and institutional affiliations.

Copyright: (C) 2022 The Author(s), published by IDEA PUBLISHERS (IDEA Publications Group).

Licensing: This is an Open Access article published under the Creative Commons AttributionNonCommercial 4.0 International License (http://creativecommons.org/licenses/by-nc/4.0/) 


\section{Introduction}

Orientalism written by Edward Said in 2003 is a masterpiece among the academic endeavours of its kind. This is a landmark and unique perspective that helps researchers comprehend the "power relationships" between the East (the Orient) and the West (the Occident). This is a perspective which helps to explore and articulate a "deep rooted idea" in the Western culture i.e., "the West is superior to the East", according to Said (2003), which rationalizes the Western imperialism. The author claims that the West with the help of their media has fashioned a deceitful image of Islamic cultures (Said, 2003).

The "other" is a key concept in the orientalism (Said, 2003) wherein it is illustrated as "people living in the East and depicted as exotic and opposite to the 'occident' and 'progressive' Western World" (Said, 1978; 2003; Roy, 2009). However, many other academics and scholars in diverse fields like; feminism, philosophy, cultural studies etc have used and incorporated the concept of "Other" in their research and studies (Wadumestri, 2010; Ghauri et al., 2021; Umber et al., 2021;).

The idea of the "other" stems from the Edward Said's concept of Orientalism wherein the West perceives Islam as "inferior", "strange", and "threatening" other (Said, 2003, p. 3). Said argues that the Orientalism has its roots in the polarization of the occident West and the orient "other". Said $(1978 ; 2003)$ maintains that the media in the West has portrayed the East as their "other" with the help of misrepresentations. The doctrine of "orientalism" has been coined with political intents wherein the orient i.e., the East has been assumed and portrayed according to the Western experience of the orient instead of understanding it according to its true nature. Said believes that such misrepresentations have transformed into stereotypes while the media with the help of latest technology has fastened and solidified this process (Wadumestri, 2010).

The "other" is anyone "separate" from someone's (imperial/powerful) own self. The "other" is fundamental and crucial in constructing one's own identity (Ashcroft et al., 2013). Spivak (1985) coins the term "othering" for a process in which the discourse of power is creating where the "other" is "mastered", "marginalized", and "excluded". Spivak puts forward three examples of "othering" process; the first is "worlding" (identification) whereby the "consolidating the self" is occurred. Second one is the "debasement" (negativization) whereby the "other" is described in terms such as "brutality", "treachery", "perfidy", "depravity", and "surrender". Third example is the "separation" (exclusion) of the "other" from "our" self (Spivak, 1985, p. 134-135). It is pertinent to mention that "othering" is a multi-dimensional process as described by Spivak (1985). It covers many social differentiations and also deals with different aspects of the society.

The concept of 'self' and "other" is most rampant in Beauvoir's (1997) "The Second Sex". Beauvoir (1997) explained the importance of gender while theorizing the concept of 'othering' as how males are regarded as the 'standard' and females as the "other". Referring to Hegel's concept, Beauvoir gave more universalization to the theory of 'self' and "other" in relations of both genders as well as other hierarchical social differences.

In general terms anyone "separate" from oneself is considered as the "other" and the existence of the "other" is essential and fundamental for one's own identity (Ashcroft et al., 2013). Gayatri Spivak introduced the term "Othering" for the "process in which the imperial discourse 
creates its other" (Spivak, 1985; Ashcroft et al., 2013). The term refers to the psychological and/or social methods by one group (imperial/powerful) to "marginalize", and "exclude", and "master" the "other". The "othered" people/groups are to be "homogenized" and "collectivized" into iconic "they" (Pratt, 1985, p. 139).

Alexander published a book "the civil sphere" in 2006 which explores the role cultural structures play in democratic societies and life. His Civil Sphere Theory (CST) emphasizes and focuses on the "role of culture and communication" played in social movements and struggles in the democratic societies. The theory provides a conceptual framework to the researchers and scholars to analyse the role of communication and journalism. The theory is an empirically grounded framework that compares the real societies with ideal civil societies (Forde, 2015). This research endeavour is effort to scrutinize the editorial coverage of the Australian press regarding Islam and Muslims according to the "solidarity discourse" and the role of communication journalism suggested by the civil sphere theory.

When it is imperative that the civil sphere theory offers a considerable help in the shape of a theoretical framework in understanding and conceptualizing the role of media in struggles for justice in democratic societies, it is also important that there are certain loopholes and drawbacks associated with the theories by critics around the globe. For example, John Nerone challenges that the theory pays little heed to the "hegemonic orders" of a society wherein the journalism organizations/institutions work and exist. Nerone prefers Habermas' notion of public sphere, in order to understand and suggest what kind of role media/journalism institutions ought to play in a particular society, and Gramsci's theoretical framework, with the aim of elucidating the empirical role of media as an institution in contemporary social and political struggles (Khan et al., 2021a; Khan et al., 2021b; Forde, 2015).

Dave Nord expresses his reservations on the theory for too narrowly focusing only on one particular "face of power" and overlooking other power structures in the social world. Nord suggests that the "civil sphere theory" is simply a "discourse" and just a "political vocabulary". However, Sid Bedingfield appreciates the theory for its "normative and empirical capacities" to analyse the "role of communication and journalism" in political contents. Rick Pop, on the other hand, advocates the theory for its focus on the culture of media but he argues that the theory pays little attention towards the "business" and "consumer practice" related to media institution. He claims that "the capitalism has its own culture and media are part of the "built environment' of the capitalism". This aspect needs to be considered while analysing the role of media in "making and unmaking of solidarity" (Forde, 2015).

The interests of journalists inevitably influence their journalistic role and function. Especially from a "cultural-sociological perspective" the narratives produced by journalists can be understood as indicators of specific 'cultural values' that go beyond certain parties, communities, and sections. The media narratives, overtaken by the "ideological power spheres", may mirror certain "autonomous cultural values" which are universal in all Civil Society (Luengo, 2012).

So, Edward Said's orientalism and many other research findings have evidenced the positive in-group (Us/the West/the Occident) and negative out-group (Them/the Islam and Muslims/the East/the Orient) discourse in the representation of Islam and Muslims by global media. However, Alexander (2006) asserts that the media being "communicative institution" of a 
society plays an important role of "civil repair" by producing a "solidarity discourse". His Civil Sphere Theory proposes that the media as a "vital centre" highlight and generates common understanding of the solidarity which can resist "non-civil" polarization and radical actions in civil societies. The study at hand has incorporated the Civil Sphere Theory as a lens to examine the editorials of the designated Australian newspapers concerning Islam and Muslims for the "solidarity discourse" and for the "civil repair".

Therefore, this study is based on one question i.e., "whether and to what extent the Australian newspapers; The Age and The Australian, produced the 'solidarity discourse' regarding Islam and Muslims from January 01, 2016 to March 31, 2017'? This research endeavour is an effort to explore the "solidarity discourse" with respect to Islam and Muslims in the editorial contents of the selected newspapers during the said time period. For this purpose, two major newspapers; The Age and The Australian, have been selected. The selected newspapers have distinctive features in the Australian media that are pertinent to this study. For the purpose, the researcher has focused on the editorials considering their vitality in the newspaper contents. The editorials are considered as manifestation and expression of the overall policy of the newspapers. Also, they are believed to be the writings that can educate, change, and/or make opinions and minds of the readers. Therefore, the editorials are selected to make the analyses of images, themes, and portrayals easier for the researchers.

The editorial contents are considered as the "solidarity discourse" wherein there are themes in the favour of Islam and Muslims representing them as victimized, supporting their rights, highlighting their problems, supporting the understanding and the multiculturalism, supporting the refugees, criticizing "us" for biased and prejudiced policies towards Muslims, and considering "them" as part of "us'. The editorial contents which emphasized on the "universalistic ties/terms", "social/civil solidarity", "we-ness", "rights", "community of society", and "peoplehood" regarding the religion of Islam and the Muslims are presented as the "solidarity discourse".

\section{Literature review}

Alexander (2006), drawing on Habermas' theory of "public sphere", Gramsci's "cultural Marxism" Durkheim's “civil morals", Rawls' vision of "democracy and justice", Weber's "fraternization", Tocqueville's "democracy" and Parson's "societal community", proposes a theory of "social solidarity and justice". The "civil sphere theory", as argued by Alexander in his book "The Civil Sphere", is mainly based on the concept of "cultural structure" (Luengo, 2012). He places "journalism and other communicative institutions" at the core of the cultural structure. According to the Civil Society Theory (CST) "narratives play a vital role in the construction of a cultural system" (Luengo, 2012). The cultural structure, according to Alexander, is relatively autonomous from "instrumental interests".

The starting point of Alexander's theory (CST) is that "the interests of 'self-interests and power' are not the only instruments that outline and frame societies but feeling for others, integration, and the ideals of community and justice are also vital" (Luengo, 2012). The "social solidarity" that stems from a socially deep rooted "symbolic structure" gives autonomy to the "institutions and discourses of civil society" from "economic and political power". The social solidarity is possible because of the fact that people are not only interested in 'here and now' and but in the 'transcendent', in the 'ideal' and in something they believe will be 'everlasting'. 
The civil society, comprised of civil institutions and associations, has some "moral codes that are not external but inherent from the society itself" (Luengo, 2012, p. 38).

Alexander proposes a new concept of the civil society which counters "two traditional idealtype understandings" (Luengo, 2012, p. 39). "Civil Society I", derived from the works of Gramsci, Hegel, Locke, Rousseau etc, is an umbrella-like notion that refers to a large number of institutions outside the state including markets, religion, associations, relationships etc (Alexander, 1997; Friedland, 2007). "Civil Society II", primarily attributed to Marx, mainly focuses on capitalist institutions and markets. Alexander proposes the concept of a "Civil Society III" wherein he emphasizes the need of understanding the civil society as a sphere. This is a "sphere which is independent from state, market, and other social spheres including religion or family life" (Alexander, 1997; Luengo 2012, p. 40; Friedland, 2007). Alexander claims that such other spheres may be required to create the civil sphere, but they are inadequate to uphold it.

"Civil society should be conceptualized as a realm of solidarity, a 'we-ness' that simultaneously affirms the sanctity of the individual and these individuals' obligation to the collectivity. The solidarity sphere, in principle and in practice, can be differentiated not only from markets and states but from such other noncivil spheres as religion, family and science [...] Civil society is an arena in which social solidarity is defined in universalistic terms (that appeal to highly generalizable values such as rights and peoplehood). It is the 'we-ness' of a national community taken in the strondest possible sense, the feeling of connectedness to 'every member' of that community that transcends particular commitments, narrow loyalties and sectarian interests. Only this kind of solidarity can provide a thread of identity uniting people dispersed by religon, class or race" (Alexander, 1997).

So, the "civil society can be envisioned as an autonomous social order; a universalizing community with its own discourses, organizations, and institutions" (Luengo, 2012). For Alexander, the civil society has two kinds of institutions: "communicative" i.e., the media and public opinion, and "regulative" i.e., law, offices, and political parties. The media is more likely to produce the social solidarity because it has the potential to broadcast representations.

After establishing the analytical difference between "civil" and "anti-civil spheres", Alexander illustrates their "mutually beneficial influence and the repression that originates from extracivil domains with intermediary 'boundary processes' from both the civil and extra-civil spheres". Alexander argues that there are three ideal types to understand these boundaries: "facilitating inputs", "destructive intrusion", and "civil repair". Certain actors and actions from other spheres can be considered as "reinforcements (inputs)" or "aggressions (destructive intrusion)". According to Alexander, "after being attacked, the civil sphere may re-establish and repair the boundary using the media, social movements in favour of civil associations, and justice, etc." (p. 40).

"... the media are one of the communicative institutions of civil society along with the public opinion, polls, and association (these are institutions with primarily cultural influence rather than power in instrumental sense). Within the symbolic structure of civil society, the news has the potential to translate 
common cultural codes into specific descriptions and evaluations of events, actors, goals, and situations. ...the role of journalistic narratives to reflect purifying motives, social relations, and institutions (or their opposites) is crucial" (Friedland, 2007; Luengo, 2012, p. 41).

CST is different from conflict or modernization theory in that it offers comparatively more "cultural", "dynamic", and "democratically oriented" model of modern-day society (Alexander, 2016). According to CST the civil sphere is "an idealized imagined community in every civilization and nation". It is aspiration and institutional at the same time. "Collective obligations" and "individual autonomy" are intertwined in an idealized civil sphere (Alexander, 2016). The civil sphere becomes incorporative and responsive because the "democratic motives and relationships" are sustained by the "cultural codes". Ethnic life, religion, family, state, and economy are considered as outside this "solidarity sphere". The anti-civil spheres are the pressures that hinder the process of "civil-repair". For example, the social movements, striving for expanding the civil sphere and for gaining "inclusion", sometimes becomes counterproductive by narrowing the solidarity and by creating "exclusions" (Alexander, 2016).

According to Alexander (2016) inside the civil sphere there are two kinds of vital institutions: "communicative" and "regulative". Communicative ones are media, both new and old one, which criticize and interpret ongoing incidents and the "actors" who are involved in them. The "regulative institutions" include voting and law which employ rewards and sanctions to concretize the interpretations. They exercise "control" over state bureaucrats and the incomes/revenues. Alexander (2016) suggests that the "discourse of the civil sphere is binary".

"To be familiar with rationality, we need to recognize irrationality; for honesty, deceit; for freedom, slavery. The discourse of civil society stigmatizes some people and groups as evil, as threatening and anti-civil, even as it purifies others as democratic and good" (Alexander, 2013, p.75; Luengo, 2012, p. 41).

The "civil sphere theory" has been employed in various parts of the world as theoretical foundation in variety of disciplines and research areas including race riots, war, economic inequality, uprising of the Arab Spring, civil war, polarization, genocide, immigration conflicts, ethnic conflicts etc (Alexander, 2016).

Drawing on the "civil sphere theory" proposed by Alexander (2006) and Luengo and Ihlebaek (2019) explored media discourses from three countries in the aftermath of the "Charlie Hebdo" attack in France. They proposed that the media can play a key role in highlighting and generating common understanding of the "solidarity" which can resist "non-civil" polarization and radical actions in civil societies. Their findings showed that the majority of the press coverage after the attack contained a "solidarity discourse". The newspapers constructed a wide inclusion discourse wherein those who believed in "freedom and liberal democracy" were included and those were excluded who did not believe so i.e., the extremists of all kindsreligious and far-right extremists. Strong language was employed in terms of describing the brutal attack, the terrorist attack was contextualized in terms of 'marginalization' and 'exclusion' problems faced by the French society, and the radical out-groups (religious and far-right) were excluded despite their ethnic origins and nationality. The researchers argued that the newspapers employed the in-group and out-group mechanism in careful manner to evade more polarization of the society between "ordinary Muslims and the West". So, the 
media strived to construct an "idealized civil sphere" that exists beyond the boundaries of religion, race or nationality (Luengo \& Ihlebaek, 2019).

Inspired by the work of Alexander this study attempts to dig out the "solidarity discourse" from the editorial contents related to Islam and Muslims in the Australian newspapers. The editorial contents which emphasized on the "universalistic ties/terms", "social/civil solidarity", "weness", "rights", "community of society", and "peoplehood" regarding Islam and Muslims are presented as "counter discourse" and theoretically are considered as the "solidarity discourse" in this study.

\section{Research methodology}

\subsection{Data collection and sampling}

This study is devoted to exploring the editorial contents of two Australian newspapers: The Age and The Australian. The Age is a Melbourne based daily national newspaper. It is being published since 1854 in a compact format. It is owned by Fairfax Media and is ranked as $6^{\text {th }}$ highly published newspapers in Australia. According to the "Audit Bureau of Circulations" (2017) maximum circulation of the newspaper is 83229 on weekdays and an average 115,256 copies on weekends. The Age is known as a reputable metropolitan daily newspaper which provides insightful analyses, accurate and comprehensive reporting along with breaking business, world, and local news (The Age, 2017). On the other hand, The Australian is a Sydney based Australian daily national newspaper being published since 1964 in a broadsheet format. It is owned by News Corporation and is ranked as one of the biggest and highly published newspapers in Australia. According to the "Audit Bureau of Circulations" (2017) maximum circulation of the newspaper is 94,448 on weekdays and average 2,19,242 copies on weekends (The Australian, 2017).

Originally, the researcher has analysed 11 editorials from each newspaper as a sample during the time period under study. All the 22 editorials in the sample were selected employing "census sampling" and then "data cleansing" on all the data selected from LexisNexis. Employing this credible data resource and by using key terms "Islam" and "Muslim" the researcher extracted editorials from both the chosen newspapers during the time period under study. According to the search results there were 24 editorials ("OPINION; Leaders") in The Age and 173 editorials ("COMMENTARY") in The Australian regarding Islam and Muslims. Using the "data cleansing" technique 11 editorials from The Age and 93 editorials from The Australian were cleaned out after careful reading. The left-out editorials contained the word "Islam" and/or "Muslims" out of the context or were irrelevant to the scope of the study. In the next step to achieve the equal number of the sample the researcher incorporated the "systematic sampling". Drawing on the " $\mathrm{K}$ th selection" method, " $\mathrm{k}=\mathrm{N} / \mathrm{n}$ " (here " $\mathrm{k}$ is the ratio", $n$ is the "sampling frame" and $n$ is required sample size), (Bhattacherjee, 2012, p. 67) all the 93 editorials of The Australian were ordered in terms of date of publication and the $N=93$ was divided by the $n$ as " $93 / 11$ " and then every $8^{\text {th }}$ editorial item was picked as sample. In this way the required and equal sample size of 11 editorial items was picked from The Australian.

As for as the time period is concerned the researcher has selected quite recent past of the study. The issue of portrayal and construction of Islam and Muslims in the global media is a widely studied and continues phenomena. It is not a time or specific incident bound phenomenon. 
Researchers around the globe have produced evidence that the coverage and portrayal of Islam and Muslims in international media is problematic (Poole, 2002). So, the researcher has concentrated on the editorial treatment of Islam and Muslims in the selected Australian newspapers to explore the solidarity discourse regardless of the time and incident dimensions. This study focuses only on the editorials from two Australian newspaper during a specific time period. The findings are limited to a particular time frame, only two newspapers and to their editorials only. For more extensive study and more generalizable findings the future research can be expanded to a wider sample size, larger time frame and to other news contents.

\subsection{Data analysis}

Critical Discourse Analysis (CDA) is a strategy that helps in studying, both theoretically and methodologically, the "power dominance" and "inequality" in communication, discourse and language. Originally the bases of the CDA are founded in the premises of Critical Semiotics (CS) and Critical Linguistics (CL) paradigms. The CDA approach is recognized as an overtly advocatory and supportive study of the "marginalized" sectors of a society (van Dijk, 1995a). The principles, basics and rudiments of the CDA also include a thorough inspection of the various "discursive practices" that convey "dominant ideologies" of the "elite" to the public and the discourses of "resistance" by the ordinary to that dominance. Consequently, the CDA focuses on a "two-way flow of communication; the top to bottom and from bottom to top, which completes the hegemonic process effectively" (van Dijk, 1993).

The major emphasis of CDA is on the discourses of dominance or resistance to the dominance by members of a social system to showcase inequality. CDA is considered to be the most appropriate approach to study the different forms of social discrimination like; racism, xenophobia, sexism, colonialism and/or Islamophobia (Reisigl \& Wodak, 2005). CDA studies include inspection of texts from different perspectives, like, grammar, rhetoric, style, discursive strategies, and socio-political contexts. A primary objective of CDA is to highlight and reveal the latent ideologies that dominant groups deploy in their discursive enactments to maintain their power relations and influence on the people (van Dijk, 1995a). Since the reproduction of dominance on the societal level is a complicated phenomenon, a range of implicit modes of reproduction needs to be analysed like; legitimization, representation, denial, mitigation and even concealment of power dominance (van Dijk, 1993).

According to Fowler (1991), if we believe that "language is a social practice" that creates "reality" and that anything written or said is interpreted through certain ideological position, then CDA advocates critical examining of the newspaper language (Fowler, 1991; Shojaei et al., 2013). According to the CDA model of van Dijk (2004), three components; discourse, cognition, and society, demonstrate that how discourse can mirror 'social ideologies.' Discourse here means written text, speech, gestures, and facial expression etc. Cognition refers to social and/or personal understanding, beliefs, and evaluations in the discourse. And society means relationships at local and/or global levels, and global societal structures, including group/subgroup relations and political systems (Shojaei et al., 2013). van Dijk maintains that the social problems can only be studied in a descriptive, explanatory and especially way by considering all these three components (van Dijk, 2004, p. 98).

van Dijk (1998b) argues that there are no "standard ways" of doing CDA and ideological scrutiny and analysis of editorials and other forms of text but he proposes few suggestions for 
doing ideological analyses which are (i) Examine the "context of the discourse"; (ii) analyse "groups", "power relations" and "conflicts" involved in the discourse; (iii) map out "positive" and "negative" opinions about "Us" and "Them"; (iv) identify "presuppositions" and "implications" and (v) analyse all "formal structures" that emphasize/deemphasize the "polarized group opinions" (van Dijk, 1998b, p. 61).

Some critics of critical discourse analysis are of the view that CDA naively assumes that discourses hide prejudice. They criticize that the adherents of this approach purposely prefer those texts which support their claim, in other words they assume it as too subjective or biased (Widdowson, 1995; Hammersley, 1997). But the proponents of CDA counter the argument by describing the very nature and premise of CDA that it explicitly takes the position of critical examining and sides with the dominated group as it is the most realist approach in accordance with any real social problems (van Dijk, 1993).

\subsection{Ideological square}

The idea and the conception of "ideology" holds a "central" position within the overall arguments and deliberations of the CDA. Ideology is a "collective belief system" or a "set of ideas" shared by the members of a society so as to create their own unique "social representation" (van Dijk, 2000). Since such an "ideology" is an outcome of a "social cognitive function" so it can be "developed, revised and abandoned gradually" by the members of the social system through an "everyday discursive process". "Social image" or the "social identity" of a particular social group or of an individual is an integral feature of the ideology which gives rise to a "political phenomenon" called "in-group" versus "out-group" polarization (van Dijk, 2006). This means that, every so often, the ideologies are "polarized" in nature especially when they belong to or related to. This simply means that ideologies sometimes have "polarized nature" when they belong to the contrasting, conflicting and/or opposite social groups- for example, consider the discourses regarding the "racial prejudice" regarding immigrants (van Dijk, 1998a).

This is how an "Us" versus "Them" dichotomy is created wherein the image of an individual or group members of an "in-group" is portrayed in a good manner by highlighting positive elements. The members of the "in-group" employ positive terms for "self-presentation". On the other hand, at the same time, they highlight "negativity" by deploying negative terms and elements of the members from an "out-group". The "in-group" members highlight negatives of the "out-group" members for the presentation of the "other". Similarly, they "mitigate" or "de-emphasize" their own negative features while intensifying and highlighting negativities of their antagonists i.e., the "other" (van Dijk, 2006). van Dijk labels this phenomenon as "ideological square" model. Basically, this model contains four distinctive discursive "moves"; a) "emphasize our good things"; b) "emphasize their bad things"; c) "de-emphasize our bad things"; and d) "de-emphasize their good things" (van Dijk, 1998a; 1998b).

The "ideological square" is an approach that helps to study and analyse positive "in-group" and negative "out-group" discursive moves. The binary positions of positive "in-group" and negative "out-group" are evident in terms of the "lexical choices" and numerous other "linguistic facets" within a discourse (Shojaei et al., 2013). The researcher has employed this approach to determine, if any, positive "in-group" and negative "out-group" moves/strategies or vice versa within the editorial discourse of the designated newspapers with respect to Islam 
and Muslims during the under-study time period. Using the "ideological square" technique the researcher has analysed the binary positions taken by the selected newspapers in their editorial contents to determine whether and to what extent the "solidarity discourse" has been produced regarding Islam and Muslims.

\subsection{Lexicalization}

Employing the positive and negative evaluations in any discourse the "ideological polarization" is evident through "lexical choices" and through many other linguistic strategies (Shojaei et al., 2013). The "lexical items" are used in a discourse to portray out-group (them/Other) negatively and in-group ("us") positively. This strategy is known as "lexicalization". van Dijk (1998b) maintains that the best-known method of analysis within the premises of the linguistic and the ideological studies is the analysis of the "lexical items". He further argues that the words, generally or contextually, are used in terms of "value judgments," "opinion", "factually" or "evaluative".

The production of polarized discourses may assume the convention of coded lexicon where the speaker might take the liberty of expressing the discourses as positive or negative presentations. Practically this implicates the choices of substitute words that are at the disposal of a speaker when representing the in/out-groups. This lexical usage can create different semantic and ideological effects on the recipients. Therefore, the analysis of the lexicalization i.e., the style of the discourse is imperative to understand and dissect the latent ideologies in any communicative event (van Dijk, 1998a). Lexicalization then connotes to the referential or nomination strategies i.e., the different choice of words available to name a person, group, social relation or an issue. This may depend on certain factors like the genre of the discourse, the mood and the opinions of the speaker, social context of the scenario and socio-cultural context means the norms and values which the speaker adheres to (van Dijk, 1995b). As an example, the discourses of right-wing political parties about the Muslim immigrants may include the negative lexical choices to represent the burden on the economy or cultural threat from refugees (Hafez, 2015). While the liberal parties may talk about the diversity of their immigrant culture that has enriched the host country in a positive lexicon or about how the migrant workers brought economic prosperity to the country.

In this study, the researcher has employed the "lexicalization" approach to explore and analyse the lexical choices opted by The Age and The Australian in their editorial contents regarding Islam and Muslims. The researcher has incorporated this technique to determine whether and to what extent the "solidarity discourse" has been produced by the newspapers regarding Islam and Muslims. So, in this research endeavour the researcher has employed the "ideological square" and "lexicalization" within the CDA premises to explore the "solidarity discourse" regarding Islam and Muslims in the editorial contents of the selected newspapers during the time period under consideration.

\section{Interpretation and analysis}

The analysis of the editorial items of The Age pointed out a prominent trend in the portrayal of Islam and Muslims. The newspaper depicted Islam and Muslims (them) in a positive way, highlighted 'their' miseries, highlighted 'their' voices, emphasized 'their' good and 'our' bad, advocated 'their' positive role in 'our' society, and supported the need for harmony, 
understanding, multiculturalism and cohesion in the society. Such a portrayal of Islam and Muslims has been categorized as a "solidarity discourse" in this study.

The editorial contents are considered as "solidarity discourse" wherein there are themes in favour of Islam and Muslims representing "them" as victimized, supporting "their" rights, highlighting "their" problems, supporting the understanding and multiculturalism, supporting refugees, criticizing "us" for biased and prejudiced policies towards Muslims, and considering "them" as part of "us". Therefore, the editorial contents are categorized as "solidarity discourse" wherein the newspaper emphasizes on "our" bad and/or "their" good. So, virtually all the editorials that are picked as sample from The Age contained a "solidarity discourse" regarding Muslims.

First editorial among the selected 11 as "sample" is "Australia must condemn atrocities in Myanmar" wherein The Age produced a "solidarity discourse" regarding Rohingya Muslims by portraying 'them' as 'victim' of 'ethnic cleansing' and by criticizing the Myanmar government for its 'indifference' to 'the plight'. The comments of The Age implying "solidarity discourse" are as follows.

The United Nations has warned that ethnic cleansing and crimes against humanity are "very likely" under way in the remote Rakhine state of Myanmar... The persecution of the Rohingya, a minority Muslim community that has been denied basic rights of citizenship in Myanmar, is longstanding... Ms. Suu Kyi has been rightly criticized for indifference to the plight of the Rohingya and not taking more forthright action in an attempt to stop the military abuses (The Age, 2017, March 16).

The editorial published on 2017, January 31 entitled; "PM's cowardly...shames us all", produced "solidarity discourse" regarding Muslims by defending Muslims of the banned seven nations "them" for not being involved in the killings of the American people (us) and by criticizing Mr. Trump (us) as a "bastardry and incompetence and bluster" regime. So, the counter discourse in the form of the emphasis on "our" bad and "their" good is visible in the comments below:

"Those who might hold the deluded belief new US President Donald Trump is showing leadership by banning, in a blatant and pathetic anti-Muslim move... Facts, not "alternative facts" - the chilling description Mr. Trump's counsellor and communications guru, Kellyanne Conway, gives to lies ... bastardry and incompetence and bluster, three unfortunate elements that marked the Trump regime... Mr. Trump, who repeatedly targeted Muslims throughout his bombastic campaign... He claims to be doing this to protect his nation from Islamist terrorism. Really? ... A US conservative policy research group, the Cato Institute, points out that the combined total of Americans killed by citizens of the banned nations between 1975 and 2015 is ... zero ... Almost 785,000 refugees have settled in the US -not one of them has committed a terrorist act... But 28 US citizens or green card (permission to work) holders have..." (The Age, 2017, January 31).

The editorial, entitled; "Indonesia tested by the raging mob", published on December 18, 2016 
produced "solidarity discourse" regarding Indonesia (other) by highlighting it "democratic transition" and "remarkable success story". So, the emphasis on "their" good is evident from the following contents: "Indonesia's democratic ... proved resilient".

In the editorial published on November 22, 2016 entitled; "Restraint is right call ... tragedy", The Age produced a "solidarity discourse" regarding an accused terrorist who belonged to Myanmar by highlighting his (their) sufferings and by criticizing those who "leap to conclusions" and "impose an explanation that suits their world view". So, the editorial contents contain emphasis on "our" bad as:

"Nur Islam, a 21-year-old man from Myanmar who fled to Australia by boat in 2013 ... causing injuries to himself and 26 others ... the absence of information will not stop people leaping to conclusions, attempting to impose an explanation that suits their world view ... Mr. Islam's state of mind has already been speculated on... he had suffered from mental problems and distress about the sickness of family in Myanmar" (The Age, 2016, November 22).

The editorial published on November 17, 2016 entitled: "US refugee ... unstuck", produced "solidarity discourse" regarding Muslims refugees (them) by highlighting "their" miseries and "our" attempt "to look strong by punishing the weak". So, newspaper's stress on "our" bad is apparent from the remarks such as "That alone is reason for caution... end the...in the Pacific...", "We also ...the weak".

In the editorial published on September 22, 2016 entitled: "Syrian conflict a damned dilemma", The Age produced a "solidarity discourse" by criticizing US-led coalition forces including Australian (us) for a "botched strike" and by highlighting "our" "parsimonious attitude" towards "those in need". So, the "solidarity discourse" emphasizing "our" bad and portraying "them" as "victims" is manifested from the following comments.

"...what has been admitted having been a botched air strike in Syria... a right and understandable concern is evident in the Australian community about what led to this clear failing... It is incumbent on the government to give a forthright and public accounting of Australia's participation in this strike... it seems an absurd level of secrecy that the government will not even confirm... action in Syria has been undertaken alongside international partners, but without the consent of the Assad regime... The cost to children, especially, from this war has been harsh... Yet the international community has too often taken a parsimonious attitude towards support for those in need... A resolution to this vicious conflict is sorely needed" (The Age, 2016, September 22).

In the editorial published on July 11, 2016 entitled: "Western voices...grip slips", The Age produced a "solidarity discourse" regarding Muslims in the Middle east by portraying 'them" as "victims' and by emphasizing "our" bad as; "relatively muted... such slaughter". Therefore, the "solidarity discourse" appears in the form of the comments such as "The bloodiest...Iraq; The bombing 2003; Rampant corruption authorities; The relatively ... implications ... apolitical show ... us all ... Leaders ... divisions ... a global ... together ... Such efforts ... against terrorism". 
In the editorial published on 2016, July 6 entitled; "One Nation should be heard - and rebutted", The Age produced a "solidarity discourse" by criticizing the "One Nation", a right-wing political party in Australia, (us) for "fanning fears of terrorism" and for "decade of shameful dog-whistling and dehumanization". The newspaper emphasizes "our" bad and 'their' good in comments such as:

“...barring Muslims from migrating to Australia; unwinding multiculturalism; and banning the wearing of the burqa and niqab in public... a decade of shameful dog-whistling and demonization by both sides of Australian mainstream politics of people seeking asylum... Ms Hanson is wrong that immigrants are a threat... their net contribution to the economy and to our society is positive" (The Age, 2016, July 6).

The editorial published on April 21, 2016 entitled; "Real voices that must be heard", produced "solidarity discourse" regarding Muslims by projecting "them" as "real voices" and by highlighting "their" stories, and marginalization and discrimination against "them". So, the stress on "their" good is obvious from such remarks.

The editorial, entitled; "Combat evil with courage and solidarity", published on March 24, 2016 produced a "solidarity discourse" by drawing a line between terrorists (them) who murder innocent people and "united world community" (us) instead of a line between "we", the westerners, and "them", the Muslims world. The counter discourse is evident from the following comments:

"And that is only an abbreviated list of the nations that have been hit by terrorists in the past three weeks alone... Our near neighbour, Indonesia, has also been hit by dreadful terrorism... How do we combat the indiscriminate evil that is manifested through terrorism...? Not by shrinking from the enormous and complex challenges it presents... Not by surrendering to murderous and maniacal zealots... We combat evil by demonstrating unending courage as a nation, as a people and as a united world community. We combat it by reinforcing and acting out the highest qualities of humanity... We will defeat terrorists" (The Age, 2016, March 24).

In the editorial published on February 23, 2016 entitled; "Trump has...qualities", The Age used marginalized and disparaged to depict Muslims in a favourable way. So, the "solidarity discourse" containing "our" bad and highlighting "them" as "victim" is evident from the comments such as: "Put aside...Trump is not fit.... the United States".

Virtually every editorial published by The Age, during period under study, contained a "solidarity discourse" regarding Islam and Muslims portraying "them" as "victims", "resilient", "democratic", "distressed", "persecuted", "harshly treated", "deceived", "positive contributors to economy", "real voices", "part of us", "prejudiced", "marginalized", "discriminated", "innocent people", and "disparaged". Therefore, the findings are the evidence that The Age, which is a "leftist' or a "centre-left" Australian newspaper, has fashioned a "solidarity discourse" with respect to Islam and Muslims predominantly portraying 'them' in favourable way. 
The "solidarity discourse" was completely unobtainable and absent in the editorials of The Australian during time period of this study. The researcher could find only one editorial among the editorial items of The Australian during the whole time period wherein only two positive adjectives i.e., decent and peace-loving were used for Muslims. The editorial was published on July 16, 2016 with the headline; "Jihadist's deadly hit on liberty, equality, fraternity". It is also notable that both the adjectives were only contextual and were used in one part of the sentence while the second part of the sentence carried the same stereotypical 'violent' and 'securitized' image of Muslims in words such as; "Islamist fanatics", "of course", "have nothing in common with decent, peace-loving Muslims who deplore such atrocities". So, The Australian did not give any favourable coverage to Islam and Muslims within and outside Australia.

\section{Conclusion}

The researcher encountered a prominent "solidarity discourse" in the editorial items of The Age wherein the newspaper portrayed Islam and Muslims ("them") in a positive and favourable way, highlighted "their" miseries, highlighted "their" voices, emphasized "their" good and "our" bad, advocated "their" positive role in "our" society, and supported the need for harmony, understanding, multiculturalism and cohesion in the society. Virtually every editorial published by The Age, during the period under study, contained a "counter discourse" with respect to Islam and Muslims constructing "them" as "victims", "resilient", "democratic", "distressed", "persecuted", "harshly treated", "deceived", "positive contributors to economy", "real voices", "part of us", "prejudiced", "marginalized", "discriminated", "innocent people", and "disparaged". As proposed by Alexander (2006) in his book; "The Civil Sphere", such a portrayal- in this case the portrayal of Islam and Muslims by an Australian newspaper- is an effort to produce a "solidarity discourse" in attempt to create a "social solidarity" in the society required for "civil repair". Playing such a role media performs like a "vital centre" in the society (Luengo \& Ihlebaek, 2019).

This is an important outcome of this study that The Australian which is a widely circulated newspaper as compared to The Age did not produce "solidarity discourse" by any means suggested by Alexander (2006) in his "civil sphere theory". However, in terms of the orientalism and the othering perspectives proposed (Said, 1978; 2003) it can be concluded that The Australian instead of focusing on the "we-ness" within the Australian society it emphasized on the "us" versus "them" dichotomy wherein the "them" (Islam/Muslims/Orient) has been portrayed negatively. So, contrary to the reviewed literature the role of The Australian cannot be termed as the "civil repair" role proposed in the "civil sphere theory" because the editorial contents of the newspaper did not emphasize on the "universalistic ties/terms", "social/civil solidarity", "we-ness", "rights", "community of society", and "peoplehood" regarding Islam and Muslims.

Drawing on the "civil sphere theory" proposed by Alexander (2006), this study attempted to determine the "solidarity discourse" with respect to Islam and Muslims in the editorial contents of the selected newspapers during the period under study. The solidarity discourse related to Islam and Muslims found in the editorial contents of The Age is an important trend but given the huge difference in the readership of the selected newspapers, this solidarity discourse and its vitality is suppressed by the negative discourses produced by The Australian in bulk. Since The Australian is a widely circulated and highly read newspaper in Australia as compared to The Age, so the negative image of Islam and Muslims would have cultivated fear, hatred and 
prejudice in the minds of the readers regarding Islam and Muslims. Such an image of the "other" strengthens biased and prejudiced political policies and discriminatory public behaviour against "them". Therefore, the findings of Luengo (2012) and Luengo and Ihlebaek (2019) are validated to the extent of The Age but the notion of "social solidarity" and "civil sphere theory" could not be approved from the editorial discourses of The Australian.

The Age has constructed Islam and Muslims in a positive and favourable way during a time of "division" and polarization between the "us" and the "them" in the Australian society. Such a depiction would help the Australian people to know and understand Islam and Muslims as part of "us" which would increase the concept of "we-ness" in the society. However, the impact of such depiction would have been manifold if the widely circulated newspaper; The Australian, has produced the same "solidarity discourse". The absence of the "solidarity discourse" and the projection of Islam and Muslims negatively by The Australian would be detrimental for the Australian society.

\section{References}

Alexander, J. C. (1997). The paradoxes of civil society. International Sociology, 12(2), 115133. https://doi.org/10.1177\%2F026858097012002001

Alexander, J. C. (2006). The civil sphere. Oxford University.

Alexander, J. C. (2013). The dark side of modernity. Cambridge University.

Alexander, J. C. (2016). Progress and disillusion: Civil repair and its discontents. Thesis Eleven, 137(1), 72-82. https://doi.org/10.1177\%2F0725513616674405

Ashcroft, B., Griffiths, G., \& Tiffin, H. (2013). Post colonial studies; The key concepts (3 ${ }^{\text {rd }}$ Ed.). Routledge.

Audit Bureau of Circulations. (2017, February 25). ABC Circulation Results-Feb 2017. https://mumbrella.com.au/abcs-weekend-nationals-grow-circulation-metro-weeklynewspapers-continue-decline-427101

Beauvoir, S. D. (1997). The second sex. (H. M. Parshley, Trans.) Vintage.

Bhattacherjee, A. (2012). Social science research: Principles, method and practices. USF Tampa Bay Open Access Textbooks.

Forde, K. R. (2015). JCI, civil sphere theory Issue. Journal of Communication Inquiry, 39(2), 111-112. https://doi.org/10.1177\%2F0196859915581078

Fowler, A. E. (1991). How early phonological development might set the stage for phoneme awareness. Phonological processes in literacy: A tribute to Isabelle Y. Liberman, 106, 97-117. https://files.eric.ed.gov/fulltext/ED340053.pdf\#page $=63$

Friedland, L. A. (2007). The civil sphere - by Jeffrey C. Alexander. Journal of Communication, 57, 599-612. https://doi.org/10.1111/j.1460-2466.2007.00359 3.x

Ghauri, M. J., Haq, A., \& Alam, R. (2021). Exploring the discourse of National Islam and Foreign Islam in the Australian press: A critical discourse analysis. Journal of Humanities, Social and Management Sciences (JHSMS), 2(2), 302-317. https://doi.org/10.47264/idea.jhsms/2.2.22

Hafez, F. (2015). The refugee crisis and Islamophobia. Insight Turkey, 17(4), 19-26. https://www.insightturkey.com/commentaries/the-refugee-crisis-and-islamophobia

Hammersley, M. (1997). On the foundations of critical discourse analysis. Language \& Communication, 17(3), 237-248. https://doi.org/10.1016/S0271-5309(97)00013-X 
Khan, A., Ghauri, M. J., \& Alam, R. (2021a). Exploring the 'civil repair' function of media: A case study of the Christchurch Mosques shootings. Journal of Development and Social Sciences, 2(IV), 467-484. http://dx.doi.org/10.47205/jdss.2021(2-IV)40

Khan, Z., Ghauri, M. J., \& Alam, R. (2021b). Exploring the 'civil repair' role of media: A Case study of the Easter bombings in Sri Lanka. Pakistan Social Sciences Review, 5(4), 531-546. https://pssr.org.pk/issues/v5/4/exploring-the-civil-repair-role-of-media-acase-study-of-the-easter-bombings-in-sri-lanka.pdf

Luengo, M. (2012). Narrating civil society: A new theoretical perspective on journalistic autonomy. $\quad$ Comunicacion $Y \quad$ Sociedad, $\quad X X V(2), \quad 29-56$. https://revistas.unav.edu/index.php/communication-and-society/article/view/36161

Luengo, M., \& Ihlebaek, K. A. (2019). Journalism, solidarity and the civil sphere: The case of Charlie Hebdo. European Journal of Communication, 34(3), 286-299. https://doi.org/10.1177\%2F0267323119844411

Poole, E. (2002). Reporting Islam: Media representations of British Muslims. Tauris.

Pratt, M. L. (1985). Scratches on the face of the country; or, What Mr. Barrow Saw in the Land of the Bushmen. Critical Inquiry, 12(1), 119-143. https://www.journals.uchicago.edu/doi/abs/10.1086/448324

Reisigl, M., \& Wodak, R. (2005). Discourse and discrimination: Rhetorics of racism and antisemitism. Routledge.

Roy, S. (2009). Media representations and 'othering' of the UN in US Media in times of conflict Post 9/11. PhD Thesis, Washington State University.

Said, E. W. (1978). Orientalism. Pantheon Books.

Said, E. W. (2003). Orientalism. Penguin Books.

Shojaei, A., Youssefi, K., \& Hosseini, H. S. (2013). A CDA approach to the biased interpretation and representation of ideologically conflicting ideas in Western Printed Media. Journal of Language Teaching and Research, 4(4), 858-868. http://www.academypublication.com/issues/past/jltr/vol04/04/28.pdf

Spivak, G. (1985). 'The Rani of Simur'. In F. Barker, Europe and Its Others Vol. 1 Proceedings of the Essex Conference on the Sociology of Literature. University of Essex.

The Age. (2016, February 23). Trump has none of a president's qualities.

The Age (2016, March 24). Combat evil with courage and solidarity. http://www.nexis.com

The Age. (2016, April 21). Real voices that must be heard.

The Age. (2016, July 6). One Nation should be heard - and rebutted. http://www.nexis.com

The Age. (2016, July 11). Western voices must swell as IS grip slips.

The Age. (2016, September 22). Syrian conflict a damned dilemma. http://www.nexis.com

The Age. (2016, November 17). US refugee deal could quickly come unstuck. http://www.nexis.com

The Age. (2016, November 22). Restraint is right call after bank tragedy.

The Age. (2016, December 18). Indonesia tested by the raging mob.

The Age. (2017). Source information. https://www.nexis.com/results/shared/sourceInfo.do?sourceId=F_GB00NBGenSrch .T25501762415

The Age. (2017, January 31). PM's cowardly stance shames us all. .

The Age. (2017, March 31).Australia must condemn atrocities in Myanmar.

The Australian. (2016, July 16). Jihadist's deadly hit on liberty, equality, fraternity. http://www.nexis.com 
The

Australian.

(2017).

Source

information. https://www.nexis.com/results/shared/sourceInfo.do?sourceId=F_GB00NBGenSrch $\underline{\text { T26708005099 }}$

Umber, S., Ghauri, M. J., \& Haq, A. (2021). Exploring the othering discourse in the Australian Press. Journal of Media \& Communication, 2(1), 52-67. http://jmc.ilmauniversity.edu.pk/arc/Vol2/i1p4

van Dijk, T. (1993). Principals of critical discourse analysis. Discourse and Society, 4(2), 249283. https://doi.org/10.1177\%2F0957926593004002006

van Dijk, T. (1995a). Aims of critical discourse analysis. Japanese Discourse, 1, 19-27. http://discourses.org/OldArticles/Aims\%20of\%20Critical\%20Discourse\%20Analysi $\underline{\text { s.pdf }}$

van Dijk, T. (1995b). Discourse analysis as ideological analysis. In C. Schaffine, \& A. L. Wenden, Language and peace (pp. 17-33). Routledge.

van Dijk, T. (1998a). Ideology a multidisciplinary approach. Sage Publications.

van Dijk, T. (1998b). Opinions and ideologies in the press. In A. Bell, \& P. Garrett (Eds.), Approaches to media discourse (pp. 21-63). Blackwell.

van Dijk, T. (2000). Ethnic minorities and the media, news racism: A discourse analytical approach. Buckingham Open University Press.

van Dijk, T. (2004). Politics, ideology and discourse. In K. B. (Ed.) (Ed.), Encyclopedia of Language and Linguistics (pp. 728-740). Elsevier.

van Dijk, T. (2006). Ideology and discourse analysis. Journal of Political Ideologies, 11(2), 115-140. https://doi.org/10.1080/13569310600687908

Wadumestri. (2010). Being Other: The Experience of Young Australian-Lebanese-Muslims. PhD Thesis, RMIT University, Australia.

Widdowson, H. G. (1995). Discourse analysis: A critical view. Language and Literature, 4(3), 157-172. https://doi.org/10.1177\%2F096394709500400301 